\title{
Hydrogeological characterization and hydrological modeling for devising groundwater management strategies for Chennai aquifer system, Southern India
}

\author{
M Senthilkumar ${ }^{1}$ and Devadasan Gnanasundar ${ }^{1}$ \\ ${ }^{1}$ Central Ground Water Board
}

May 19, 2020

\begin{abstract}
Chennai aquifer system covering an area of $6629 \mathrm{~km} 2$ is one of the most stressed aquifer systems in southern India as groundwater is relentlessly used for irrigation, domestic, industrial purposes and for drinking water supply to ever expanding Chennai city. This heavy extraction necessitated a paradigm shift towards groundwater management. Multidisplinary-integrated approach was taken up to map the aquifers, delineate its geometry, hydrodynamic characterization and to formulate an aquifer management plan through groundwater model. Weathered \& fractures gneiss/charnockites along with alluvium form the aquifer units. Alluvium is the potential aquifer system of the region with potable quality except for the eastern/northeastern region affected by to seawater intrusion. Two-layered hydrogeological model was developed with one $\mathrm{km} 2$ grid pattern to simulate groundwater flow for nine years. The model calibrated under steady and transient conditions, allows quantifying the components of recharge, groundwater draft, and fluxes on the regional scale. Simulated results indicate that this aquifer system is under tremendous stress with the present groundwater withdrawal of $899 \mathrm{mcm}$ and becomes unstable with $25 \%$ increase in groundwater withdrawal by 2025. $54 \mathrm{mcm}$ increase in resources due to recharge measures has groundwater head build up and easterly movement of the potential lines. Scenario of maintaining 120 days flow in rivers shows increase in groundwater head and development of the groundwater mounds, which are positive signatures for arresting the decline and pushing the saline water. Regulation of groundwater abstraction and rejuvenation flow in the rivers would sustainably manage the available groundwater resources of the region.
\end{abstract}

\section{Introduction}

Ground water is being increasingly recognized as a dependable source of freshwater to meet the demands of domestic, irrigation and industrial sectors of the country. The development activities in an unscientific manner over the years have lead to adverse situation wherein the groundwater withdrawal is more than natural recharge resulting declining in groundwater level, desaturation of shallow aquifers, increased energy consumption for lifting water from progressively deeper levels, quality deterioration and issues in sustainability of sources in many parts of the country. These scenarios not only have adverse devastating effects on the environment but also lead to subdued economic growth of the country (World Bank, 2006). This necessitated for a paradigm shift towards groundwater management. The importance of groundwater for national development has deemed its necessity to be more specific on groundwater management to aquifer management for managing it effectively. In order to manage these aquifers it is necessary to map the aquifer like know the aquifer - manage your aquifer. It is necessary to know the lateral, vertical extent of the aquifer, its recharge rates \& areas, discharge rates \& areas, its characteristics, quality and quantity (CGWB, 2012). Organizing the hydrologic data generated, quantifying the properties of the aquifer units, behavior 
of aquifer and its response to externally applied stressed can be better understood by groundwater models for effective management of groundwater resources (Senthilkumar and Elango 2004 \& De Caro et al 2017). Many researchers (Kinzelbach 1986; Anderson and Woessner 1992; Heinl \& Thorweihe 2007 and Waston et al 2015) have demonstrated the application of groundwater models to calculate the rate of flow groundwater through the aquifer units. Few researchers (Bianchi et al 2015; Idrysy \& De Smedt 2006; Sundararajan \& Sankaran 2020; Pisinaras 2007 and De Caro et al 2020) have also used models for devising effective management for improved sustainability of the groundwater resources. This paper illustrates an integrated study involving mapping of aquifers for better understanding of the hydrogeologic process that control the distribution \& availability of groundwater and development of groundwater flow model to formulate strategies for sustainable management plan was attempted for Chennai aquifer system, southern India.

Groundwater is being extracted relentlessly for irrigation, domestic, drinking water supply to Chennai city and industries in the vicinity as the rivers in the area flow only for few days in the year. The groundwater withdrawal is increasing with ever expanding \& swelling Chennai city population and a failure in the rainfall, the dependence on groundwater amplifies many folds. The paper aims to map \& characterize the aquifer units and develop a groundwater flow model to simulate regional distribution of heads, assess the impact on the aquifer system due to various hydrological stresses and to formulate efficient and sustainable aquifer management plan for improved water resources of the aquifer system.

\section{Description of Chennai Aquifer system}

The Chennai aquifer system, covering an area of $6629 \mathrm{~km}^{2}$ comprises of $341 \mathrm{~km}^{2}$ of hilly area and $6288 \mathrm{~km}^{2}$ of mappable area, is situated between latitudes $12^{\circ} 40^{\prime} \mathrm{N}$ and $13^{\circ} 40^{\prime} \mathrm{N}$ and longitudes $79^{\circ} 10^{\prime} \mathrm{E}$ and $80^{\circ} 25^{\prime} \mathrm{E}$ at the north and north east corner of Tamilnadu (Figure.1). It is bounded by Andhra Pradesh state in the north; Palar River aquifer system in the west \& south and the Bay of Bengal sea on the east. The Chennai aquifer system covers two entire districts namely Tiruvallur $\left(3534 \mathrm{~km}^{2}\right)$ \& Chennai $\left(179 \mathrm{~km}^{2}\right)$ and parts of two districts, Kancheepuram $\left(1914 \mathrm{~km}^{2}\right)$ and Vellore $\left(998 \mathrm{~km}^{2}\right)$. Twenty six administrative blocks falls within the study area and these are further divided into 109 firkas. There are four seasonal rivers Araniyar, Kosathalayar, Cooum and Adyar flowing only for few days during the monsoon period. Four major reservoirs, Poondi (Sathyamoorthy Sagar), Red Hills, Sholavaram \& Chembarambakkam and numerous rainfed ponds are present in the low-lying areas of the study area. The Chennai aquifer system experiences a subtrophical monsoon climate with 2 monsoon period southwest (June to Sept) and northeast (Oct to Dec). The normal rainfall experienced by the area is $1100 \mathrm{~mm} /$ year (100 years) with $41 \%$ \& $50 \%$ contribution by southwest and northeast monsoon respectively. Transition period and summer rains contribute to $9 \%$ of the rainfall.

Figure.1 Location map of the Chennai aquifer system.

\section{Geological setup of Chennai aquifer system}

Geologically, the Chennai aquifer system comprises of marine, estuarine and fluvial alluvium underlained by Precambrian gneisses and charnockites. The charnockites form the major rock types and constitute the residual hills around southern part of the study area. The western of the Chennai aquifer system (Figure.2) gneissic rocks are present, they cover an area of $1355 \mathrm{~km}^{2}$, and charnockite formations are found in the eastern part of the study area covering about $537 \mathrm{~km}^{2}$. Upper Gondwanas beds are observed in and around central and northern portion. The Upper Gondwana sediments consist of two stages viz. the lower Sriperumpudur stage located in the southern side consists of fluviatile clays, shales and feldspathic sandstones and the second stage Satyavedu formation located $15 \mathrm{NNW}$ of the boundary consisting of the marine sediments of ferruginous sandstones, conglomerates and boulders and at places are capped by a thick cover of laterite. Tertiary sandstone is seen in small patches in the study area ie., in the northwest of Chennai city and upto Satyavedu, and is capped by lateritic soil (Figure.2). The youngest formations in the area are the alluvium, 
which was deposited on the worn-down and eroded surface of Tertiary and Gondwana rocks by the major rivers covers an area of $2036 . \mathrm{km}^{2}$ spatially. The alluvium thickness ranges from 40 to 50 in between the two river Arani and Koratalaiyar, consists of gravel, fine to coarse sand, clay and sandy clay of various shades of grey and brown. Geologic succession of the Chennai aquifer System is presented in Table.1

Figure.2 Geological setup of the Chennai aquifer system

Table .1. Geological succession and hydrostratigraphy of the Chennai aquifer system

\section{Methodology}

Multi-disciplinary approach involving geological, geophysical, hydrological, hydrogeological and hydrogeochemical survey was carried out in 1:50000 scale in order to map and characterize the aquifer units upto $200 \mathrm{~m}$ below ground level (bgl). The preliminary work included the compilation of existing lithlog data of the exploratory borewells drilled by Central Ground Water Board (CGWB) \& state agencies. 274 nos of available exploratory well datas with complete lithological information was projected in the GIS platform and data gaps were identified. 32 nos of additional wells were drilled in the identified data gaps. 124 nos of vertical electrical sounding data was also generated in the data gaps. Aquifer parameters from 43 pumping test stations spatially distributed were also used in this study. Data available for a long period i.e., more than ten years from the groundwater level monitoring stations (211 nos) and groundwater quality monitoring station (148nos) data was also used for this study. All these data were used to define, characterize the regional aquifer units and to construct aquifer maps of the Chennai aquifer system. Cropping pattern, landuse details and soil data has been collected from Agricultural and Statistics Department. SRTM 30 m resolution data was used to construct the DEM and top elevation. Groundwater draft has been estimated using the cropping pattern and electricity consumption data. 100 years rainfall data of the rainguage stations falling within the study area were also collected from Indian Meteroloigical Department (IMD).

\section{Hydrogeological characterization}

Integration of the geological, geophysical, hydrological, hydrogeological and hydro-geochemical data delineated the presence of two distinct aquifer systems. Groundwater of the study area is found to occur in the quaternary formations (recent alluvium) in the eastern and central portion, Gondwana sandstone/conglomerates formations of the Upper Cretaceous period underlies the alluvium. Hard rock aquifers comprising of charnockites in Southeastern and gneisses in the western portion have groundwater occurrence.

\section{Pre-Cambrian hard rock aquifer units}

Hard rock region comprising of gneissic and charnockites rocks is found in the western and in the southeastern portion of the Chennai aquifer system. Hard rock regions cover an area of $1914.13 \mathrm{~km}^{2}$ has gneissic formation covering an area of $1354.7 \mathrm{~km}^{2}$ and charnockites formation covering an area of $536.5 \mathrm{~km}^{2}$. Two distinct aquifer units have been delineated based on the hydraulic parameters and groundwater level behavior in the gneissic formation and charnockite formations. Two aquifer units namely the weathered and fracture/jointed aquifer unit.

The weathered aquifer unit comprises of weathered formations, partially weathered and some extent first fractures of charnockites and granitic gneisses rock formations. It occurs from the groundwater level and has a minimum thickness of $8 \mathrm{~m}$ and maximum thickness of $30 \mathrm{~m}$ with average thickness of $18 \mathrm{~m}$. 2D disposition along west to south east (Figure. $3 \& 4$ ) clearly shows the vertical and lateral distribution of the weathered aquifer unit. Yield of this weathered aquifer unit ranges from 0.8 to $16 \mathrm{~m}^{3} / \mathrm{hr}$ (Table.2). During monsoon period (July to Dec), the wells tapping this aquifer unit sustains for only 2 to 4 hrs/day while during nonmonsoon period (April to June) sustains for less than 1 hour/day. Transmissivity of this aquifer unit ranges 
from 4 to $32.3 \mathrm{~m}^{2} /$ day and groundwater occurs in unconfined condition. Specific yield of this aquifer unit ranges from 1 to $1.5 \%$ with highly potable groundwater quality in most of the vast area of this aquifer unit. The general EC of this aquifer unit ranges from $500-600 \mu \mathrm{S} / \mathrm{cm}^{2}$ and is suitable for drinking. There are some isolated pockets adjoining the industrial cluster in Chromepet (southeastern portion) where the groundwater quality is beyond permissible limit for drinking and irrigation purposes.

Figure.3 Aquifer disposition along NW-SE direction of the Chennai aquifer system

Figure.4 Aquifer disposition along W-E direction of the Chennai aquifer system

Table .2. Basinal and hydraulic features of the Chennai aquifer system

Fractured \& jointed portion forms the aquifer unit II, this aquifer unit comprises of fractured and jointed gneissic, and charnockites formed due to tectonic activity. Top of this aquifer unit occurs from 8 to $30 \mathrm{~m}$ bgl (Figure.3 \& 4). Based on the analysis of the borehole lithologs it is observed that there is a possibility of occurrence of 3 to 4 fractures/joints exists upto $190 \mathrm{~m} \mathrm{bgl}$ in the gneissic region. In charnockites region 3 to 4 fractures are likely to be encountered and they exit only upto $155 \mathrm{~m}$ bgl. The yield of this aquifer unit II ranges from 0.9 to $12 \mathrm{~m}^{3} / \mathrm{hr}$ (Table.2). During monsoon period the wells tapping this aquifer unit sustains for 4 to $6 \mathrm{hrs} /$ day while during non-monsoon period (April to June) sustains for 1 to 3 hour/day. Transmissivity of this aquifer unit ranges from 3.57 to $45.58 \mathrm{~m}^{2} /$ day (Table.2). The general EC of this aquifer unit ranges from 320 to $1040 \mu \mathrm{S} / \mathrm{cm}^{2}$ and is suitable for drinking.

\section{Gondwana aquifer units}

This gondwana region comprises of highly compacted conglomerates of upper Cretaceous with type area being the Sathyavedu formation and is located $15 \mathrm{~km}$ of the northwestern periphery. Gondwana region covers an area of $962.40 \mathrm{~km}^{2}$ and with laterite capping, covers an area of $321.73 \mathrm{~km}^{2}$ of the Chennai aquifer system. Gondwana region forms two aquifer units namely aquifer unit I comprising completely weathered gondwana and weathered gondwana with laterite capping and aquifer unit II comprising of conglomerates/sandstone.

Weathered conglomerates and conglomerates with laterite capping forms the aquifer unit 1 and top of this aquifer unit occurs from ground level to $6.5 \mathrm{~m}$ bgl. The thickness of this aquifer unit ranges from 9 to 13.50 $\mathrm{m}$ bgl. The maximum thickness of the laterite deposit is $8.4 \mathrm{~m}$ and is observed in the southern portion of the Chennai aquifer system. 2D aquifer disposition along northwest - southeast and west - east direction (Figure. $3 \& 4$ ) clearly bring outs the disposition of the aquifer unit. Yield of this aquifer unit is very low and ranges from 2 to $21 \mathrm{~m}^{3} / \mathrm{hr}$ (Table.2). While conglomerates with lateritic capping have high yield and they range from 4 to $37 \mathrm{~m}^{3} / \mathrm{hr}$. Wells tapping complete conglomerates aquifer unit sustain for 2 to $3 \mathrm{hrs}$ during monsoon and less than hour during non-monsoon period i.e., April to June. Wells tapping the conglomerates with laterite capping sustain for 3 to $5 \mathrm{hrs}$ during monsoon and less than $1 \mathrm{hr} /$ day during non-monsoon (April to June). Transmissivity value ranges from 2.23 to $142.2 \mathrm{~m}^{2} / \mathrm{d}$. Transmissivity are very low in the completely conglomerate region while they have high values in laterite capped regions. Specific yield of this aquifer unit estimated through a long duration pumping test $(7200 \mathrm{~min})$ of the well tapping conglomerate aquifer resulted in specific yield value of $1 \%$ (CGWB 2017). Groundwater occurs in unconfined condition and $\mathrm{EC}$ in this aquifer unit ranges from 150 to $2500 \mu \mathrm{S} / \mathrm{cm}^{2}$.

Aquifer unit II comprises of conglomerates and ferrugenious sandstone with shales, which are cemented by siliceous material and pore spaces and open spaces in the conglomerates stores, and yields groundwater. This aquifer unit II occurs below the weathered conglomerates and extends upto $764 \mathrm{~m}$ in the central portion of the study area (CGWB 2017). The top of this aquifer unit extends from 9 to $13 \mathrm{~m} \mathrm{bgl}$ and has thickness ranging from $8.6 \mathrm{~m}$ to beyond $300 \mathrm{mbgl}$. 2D aquifer disposition along northwest-southeast and west-east (Figure. $3 \& 4$ ) clearly shows the maximum thickness of this aquifer unit in the central portion of the study area. Yield of this aquifer unit ranges from 2 to $8 \mathrm{~m}^{3} / \mathrm{hr}$ (Table.2) and can sustain for 1 to 2 hours /day during monsoon and less than 1 hour/day during non-monsoon period (April to June). EC values in this 
aquifer unit ranges from 100 to $2125 \mu \mathrm{S} / \mathrm{cm}$. Groundwater is generally potable except for few locations along the eastern part.

\section{Alluvial aquifer}

Alluvium is the youngest formation of the study area and covers a major portion of the study area (2036 $\mathrm{km}^{2}$ ). Recent alluvium forms the principal aquifer unit in this region and comprises of sand, silt, gravel with clay intercalations Groundwater is developed by dugwells and tubwells and the depth of the dugwells ranges from 3 to $8 \mathrm{~m} \mathrm{bgl}$ while the depth of the tubewells ranges from 15 to $80 \mathrm{~m} \mathrm{bgl}$. The central portion (Figure.2) of the study area i.e the regions between the two rivers, Arani \& Koratalaiyar river the depth of this aquifer unit is maximum and ranges from 30 to $50 \mathrm{~m} \mathrm{bgl}$ (Figure.3 \& 4). Yield of this aquifer unit is very high and ranges from 68 to $142 \mathrm{~m}^{3} / \mathrm{hr}$ (Table.2) and there are no sustainability issues in this aquifer unit. Transmissivity value ranges from $807 \mathrm{~m}^{2} /$ day (Vallur Village) to $4180 \mathrm{~m}^{2} /$ day (Panjetty village). The specific yield value of this aquifer unit rages from 12 to $20 \%$ (CGWB 2017). Groundwater is found to occur in unconfined/semi-confined conditions in this formation. Seawater intrusion is observed in this aquifer unit and has laterally intruded upto $16 \mathrm{~km}$ inland in the northeastern portion of the study area (Senthilkumar et al, 2018)

\section{Model formulation}

The conceptualization of the Chennai aquifer system includes description of the geologic and hydrogeologic setting which were arrived from the detailed study of the aquifer mapping through geology, borehole lithology, geophysical logs, cross section and groundwater level fluctuations in monitoring wells. Groundwater of the study area is found to occur in the quaternary formations (recent alluvium), Gondwana conglomerates/sandstone formations of the Upper Cretaceous period and hard rock formations of archean period. Paleo-geographic, structural features and major depositional provinces have influenced the distribution of hydrologic characteristics of the aquifer units of the Chennai coastal aquifer.

Based on the results of the aquifer mapping and characterization of the aquifer units the Chennai aquifer system has been conceptualized as a two layered aquifer system with a combination of soft and hard rock aquifers. In the east and central portion the alluvium forms the aquifer 1 and is underlained by compact conglomerates of upper gondwana forming the aquifer II. In the southeastern and western portion of the study area the hard rock forms the aquifer system. Aquifer unit 1 comprises of weathered formation and are underlained by fractured/jointed aquifer forming the aquifer units II.

\section{Boundary conditions}

The study area the Chennai aquifer system is also a river basin boundary. The boundary conditions modeled are as per the watershed boundary. The northern boundary is the state boundary and there is movement of flux is in and out of the boundary, hence it was modeled as flux boundary. Fluxes were calculated using the transmissivity, gradient and length of groundwater head (TIL method) and were inputted in the northern boundary throughout the model period. Southern boundary is bounded by palar river basin and forms a river basin boundary and hence it was modeled as no flow boundary (Figure.5). The eastern part of the study area is bounded by Bay of Bengal sea and hence it was modeled as a constant head boundary. Four seasonal rivers namely Arani, Korratalaiyar, Coovum and Adyar flow from the west to the east and was modeled using the river package. The aquifer top and bottom were derived mainly based on the lithology of boreholes, geophysical logs and by intensive field surveys. The study area was vertically divided into two layers. First unconfined layer is comprising of the top soil and quaternary alluvium in the eastern and central portion which is underlain by Conglomerates which occurs under confined/unconfined conditions. In the western and southeastern portion the weathered portion of granitic gneiss and charnockites for the layer 
1 (unconfined aquifer) and this is further underlain by the fractured/jointed aquifer unit occurring under confined conditions forming the layer 2. Four major reservoirs situated in the model area namely Poondi (Sathyamoorthy Sagar), Red Hills, Sholavaram and Chembarambakkam and were modeled using the general head boundary.

\section{Grid Design}

The geographic boundaries of the Chennai aquifer system covering $6629 \mathrm{~km}^{2}$ was discretized with a finite definite grids of constant spacing of $1.0 \mathrm{~km}$ by $1.0 \mathrm{~km}$. The model area was divided into 120 rows. 80 columns and vertically by 2 layers (Figure. 5). The layer disposition along north south and west east clearly delineates the lateral and vertical extent of the aquifer units (Figure.6). The vertical thickness of the layers was mainly derived from the subsurface characterization described in the hydrogeological framework. The top elevation was derived from SRTM 30 m resolution data. 50000 points were randomly created within the boundary area and values of reduced level were extracted from the SRTM datasets.

Figure.5 Boundary conditions and model discretisation of the Chennai aquifer system

Figure.6 Model cross-Section along N-S \& W-E direction

\section{Input parameters}

\section{Aquifer characteristics}

The aquifer characteristics such as hydraulic conductivity, specific yield and specific storage used in the model were derived from 43 pumping tests results (CGWB 2017). In steady-state groundwater flow, the groundwater level distribution and groundwater fluxes are controlled by hydraulic conductivity (K), which depends on the intrinsic permeability of the porous media, the density and viscosity of the fluid. Hydraulic conductivity $(\mathrm{Kx}, \mathrm{Ky} \& \mathrm{Kz})$ used in the model for the layer 1 is represented in figure.7. The hydraulic conductivity values for the alluvial areas are $40 \mathrm{~m} / \mathrm{d}$ while for the conglomerate (gondwana formation) it was $2 \mathrm{~m} / \mathrm{d}$. The weathered granitic gneiss ranged from 6 to $8 \mathrm{~m} / \mathrm{d}$ while the weathered charnockitic regions ranged from 4 to $6 \mathrm{~m} / \mathrm{d}$. For the layer 2 the hydraulic conductivity values considered for the conglomerate (gondwana formation) was $1 \mathrm{~m} / \mathrm{d}$ and for the fractured and jointed granitic gneiss and charnockitic regions it ranged from 2 to $3 \mathrm{~m} / \mathrm{d}$.

The Specific yield (sy) values for layer 1 ranged from 12 to $20 \%$ for the alluvial areas while for the conglomerate (gondwana formation) it was 1\%. A small portion in the central and north-central part had laterite capping on the conglomerate formation. The thickness of these laterite beds ranged from 6 to $8 \mathrm{~m}$. Specific yield value of $4 \%$ was considered for this formation. The weathered granitic gneiss the specific yield values of $1.5 \%$ was considered while the weathered charnockitic regions if was $1 \%$. For the layer 2 storativity values of 0.003 for the fractured/jointed granitic gneiss and charnockite was considered. The gondwana formation comprising of conglomerates the storativity value of 0.002 was considered (CGWB 2017).

Figure.7 Aquifer characteristics for layer 1 of the Chennai aquifer system

\section{Initial groundwater head}

The initial groundwater head of the Chennai aquifer system was arrived based on the detailed analysis of the hydrographs, rainfall and groundwater level fluctuation. The groundwater head data of Jan 2010 represents the normal spatial groundwater distribution of the study area (Figure.8) as during this period the rainfall was also normal and the groundwater fluctuation was also representative that of a normal year.

Figure.8 Initial groundwater head (m msl) distribution during Jan 2010 


\section{Groundwater abstraction}

The discharge from Chennai aquifer system occurs as withdrawals by irrigation, industrial and public-supply wells. The public supply wells include drinking and domestic needs of the people of the area as well as drinking supply to Chennai city. Agriculture activity of the study area is mainly dependant on groundwater resource available in the area, as there is no canal network in the study area. The Landuse pattern, drainage pattern and the period of flow of water in the river shows that groundwater is used throughout the year in the of the study area. The reservoir water is not used for irrigation activity as it is protected resource for drinking water supply to Chennai city. The groundwater draft was calculated by using landuse data, electricity consumption data and yield of the wells. The domestic and drinking water requirement of the study area was calculated based on population. The total annual draft of the Chennai aquifer system is about $899(\mathrm{mcm})$ million cubic metre /yr (Table.3). The major draft of groundwater is from the aquifer unit 1 and is about $754 \mathrm{mcm}$ annually. The second aquifer unit (aquifer II) has a groundwater draft of $154 \mathrm{mcm}$ annually.

Table.3 Total annual draft of the Chennai aquifer system

\section{Groundwater Recharge}

The recharge to the Chennai aquifer system varies considerably due to differences in landuse pattern, soil type, geology, topography and relief. The recharge to the aquifer system is from rainfall, irrigation return flow and inflow from the river and storage tanks. Rainfall is the principal source of groundwater recharge. The rainfall hydrograph were studied to understand the recharge pattern in the study area. The aquifer gets recharged and groundwater level shoots whenever the rainfall exceeds $45 \mathrm{~mm}$. Alluvial, laterite, conglomerates, weaterhed granitic gneiss and changenockites geologically cover the entire portion of the study area. Five recharge zones have been demarcated in the study area and they comprise of zone 1 Alluvial areas, zone 2 Conglomerate zones, zone 3 - laterite capping on conglomerates, zone 4 - granitic gneissic areas and zone 5- charnockitic area (Figure.9). Rainfall infiltration factor used for recharge rates estimation ranged from 10 to $14 \%$ for alluvium and less than $4 \%$ for the gondwana aquifer (Table.4).

Figure.9 Recharge zones and recharge rates for the Chennai aquifer system.

Table.4 Rainfall infiltration factor estimated for the Chennai aquifer system.

\section{Model Calibration}

Model calibration strategy was carried out to vary the best known parameters as little as possible and vary the poorly known data to attain the good match between simulated and observed groundwater heads. Model calibration under steady state was carried out to reduce the dissimilarity between the simulated and observed groundwater heads. Steady state calibration was carried out with the groundwater head data of Jan 2010 from 28 monitoring network data spatially scattered over the study area. Hydraulic conductivity value was the poorly known parameter as only few pumping tests results were available for the gondwana aquifer units. Hydraulic conductivity values were varied upto $10 \%$ from the pumping test results for layer 1 to get a reasonably perfect match of the simulated and observed groundwater heads (Figure 10). Steady state calibration resulted in a very good match between the calculated and observed water heads in almost all the wells of the study area. Root mean square error was $5.74 \mathrm{~m}$ and the normalized root mean square error was $4.37 \%$. Steady state calibration was achieved through numerous runs using the trial and error method.

Model calibration under transient state simulation was performed for 9 years (Jan 2010 to Dec 2018) with monthly stress periods and 24 hourly time steps. The trial and error method was used for calibrating the transient model. After several trials runs a good match between computed and observed heads was observed spatially as well as with time. Based on the good match between simulated and observed groundwater heads 
from 28 observation wells spatially distributed over the study area, the transient models were considered to be calibrated satisfactorily.

Figure.10 Model calibration under steady and transient condition.

\section{Model Simulation}

Simulation of the flow model was carried out in transient condition for a period of 9 years from Jan 2010 to Dec 2018. There was reasonably good between the simulated and observed groundwater heads (Figure.11). Detailed analysis of the computed groundwater head of the study area reveals that the highest groundwater heads are found on the western side, which are reflection of the topography. The regional groundwater flow direction is from west to east. Simulated groundwater head for the Chennai aquifer system during May 2018 (Figure.11) shows that groundwater flow in the hard rock regions is different from the groundwater flow in the alluvial formation in the east. The groundwater head contours are closely spaced in the western part and are widely spaced in the alluvial regions of the study area. North central and western parts of the study area have dry cells. The aquifer system is under tremendous stress due to the heavy groundwater withdrawal. The concave shaped trough is observed in the groundwater head between the 50 and $25 \mathrm{~m}$ lines clearly indicating the substantial amount of groundwater withdrawal in central region. The groundwater flow vectors exhibit irregular flow pattern during the month of December, which may be attributed to the rainfall recharge and regular flow vector during the summer period. Reversal of flow vectors are also observed during the May month, which is an indication of the seawater intrusion in the eastern part of the Chennai aquifer system.

Figure.11 Simulated and observed groundwater head (m msl) during May 2018.

\section{Model prediction and aquifer management plan}

All input and output fluxes of the Chennai aquifer system and its response were analyzed in order to prepare sustainably strategies to effectively manage the aquifer system. The model was extended for a further period of 07 years from 2019 to 2025. For this predictive simulation, the data of average rainfall (100 years), last groundwater abstraction, river flow days and recharge was inputted into the model until 2025. Four prediction runs were planned to evolve optimal management schemes for the Chennai aquifer system and they are;

Projected groundwater head by 2025 with present pumping conditions

The model was run with present pumping condition to predict the regional groundwater head in this area until the year 2025. For these runs 40 years monthly average rainfall data was used along with the present level of groundwater abstraction. The simulated regional groundwater head for September 2025 (Figure.12) shows that in major portion of the study area there isn't much increase or decrease in groundwater head. Eastern portion and central portion show decrease in the groundwater head and movement of the trough towards the western direction.

Projected groundwater head by 2025 with increase in groundwater abstraction by $10 \& 25 \%$

Groundwater is the major source of freshwater for the various uses namely agriculture, drinking water supply to Chennai city, industries and domestic water supply. Groundwater withdrawal has been an increasing steadily over the years. Hence, it was considered necessary to understand the behaviour of the aquifer system to increased hydrological stress. Two major anticipated changes in the pumping pattern in future were predicted. The present annual groundwater withdrawal for aquifer unit I was $745 \mathrm{mcm}$ while in the aquifer unit II it was $154 \mathrm{mcm}$, totaling to $899 \mathrm{mcm}$ annually. The first being the possible increase in groundwater pumping by $(10 \%) 820 \mathrm{mcm}$ and $170 \mathrm{mcm}$ for aquifer unit I \& II respectively. The second scenario was generated with increase in groundwater pumping by (25\%) $930 \mathrm{mcm}$ and $192 \mathrm{mcm}$ for aquifer 
unit I \& II respectively.The impact of the increase in pumping by $10 \%$ and $25 \%$ by the year 2025 (Figure.12) indicate the westerly movement of the potential line. These scenarios indicate the decrease in groundwater head in alluvial regions of the Chennai aquifer system. With eastern side bounded by coastal boundary and already seawater intrusion is observed in the study area (Senthilkumar, 2018), Increase in groundwater draft by $25 \%$ by 2025 is will more devastating as the potential line indicate the western movement. This will further increase in the inward movement of saline water during the summer periods. No further increase in groundwater abstraction should be encouraged and demand side interventions through water use efficiency \& change in irrigation should be implemented in the region for sustainable management of the available groundwater resources.

Figure.12 Projected GW heads (m msl) during 2025 with present and increase in GW draft.

Projected GW head by 2025 with supply side interventions through recharge measures

On the basis of aquifer mapping studies of Chennai aquifer system, supply side interventions through recharge measured were formulated in regions where high declining rates of groundwater head were observed. Understanding of the disposition and extent of the aquifer system through the aquifer maps (CGWB 2017), the potential volume of void space available within the aquifer unit 1 was estimated to be $470 \mathrm{mcm}$. The annual uncommitted surplus runoff available in the study area is only $242 \mathrm{mcm}$ (CGWB 2017) which accounts for less than $50 \%$ of required water to fill the available void space of aquifer-I. Recharge measures and water conservation plan was formulated for the highly stressed zones of the study area. A total number of 23 check dams, 166nala bunds and 372 recharge shafts were proposed along with renovation \& repair of 273 nos village rainfed ponds (CGWB 2017). The expected recharge through these measures was in the order of $54 \mathrm{mcm}$ annually (CGWB 2017). $54 \mathrm{mcm}$ recharge component was applied in the calibrated model in the respective stressed zones to understand the effects on the groundwater flow system. The eastern part of the Chennai aquifer system is highly impact by the recharge measures by the movement of potential lines towards the eastern side (Figure.13). The impact is more prominent in the alluvial regions than in the hard rock regions. Eastern movement of the potential lines is a positive signature for arresting and pushing the saline water intrusion seaward side.

Figure.13. Projected GW heads (m msl) with $54 \mathrm{mcm}$ increase in recharge during 2025.

Projected groundwater head by 2025 with flow in two rivers and construction of a canal connecting two river

The model was projected until 2025 with two new strategies that could assist in arresting the decline and pushing the saline water interface towards seaward side. The $10 \%$ increase in groundwater draft was considered in this prediction scenario. The water flow in the 2 northern rivers (Arani \& Korataliayar) are very minimal, 10 to 15 days with a river head of 0.1 to $0.25 \mathrm{~m}$. Considering the same river head and if flow in the river is maintained for 120 days, the impact on the groundwater head in the Chennai aquifer system was projected. Further, an unlined canal of $10 \mathrm{~m}$ width in the proposed location connecting the Arani and Korattalaiyar river (Figure.14) was projected. The both the rivers at this point tend to move in diagonal directions. The calibrated model predicted the behavior of the groundwater heads with 120 days flow in the rivers and also predicted the impact of unlined canal connecting the rivers two rivers Arani and Koratalaiyar (Figure.14). Increase in the groundwater head in the eastern side and movement of the potential lines of 25 $m$ towards the eastern side in clearly observed. The impact is more prominent in the alluvial regions than in the hard rock regions. Development of the groundwater mounds in the eastern part is a positive signature for arresting the decline and pushing the saline water towards the seaward side.

Figure.14. Projected GW heads (m msl) with 120 days flow in rivers and impact of canal connecting Arani and Korratalaiyar river during 2025. 


\section{Conclusion}

Hydrogeological mapping and characterization study was carried out for the first time for Chennai aquifer system covering an area of $6629 \mathrm{~km}^{2}$ for formulating suitable strategies for sustainable groundwater resources management. Reconstruction of basinal history the study area reveals that has hard rock are observed in the western (Gneiss) and southeastern portion (Charnockite), while the central, northern \& eastern portion have conglomerates overlain by recent alluvium. Four seasonal rivers flowing from west to east (river flows 10 to 15 days/yr) drain through the study area.

- An integrated scientific study involving geology, hydrology, geophysical, chemical and hydrogeological investigation was done to identify the aquifer units, delineate its lateral \& vertical extent and characterize the aquifer units. Alluvium forms the principal aquifer system and has specific yield ranging from 12 to $20 \%$. The conglomerates are siliciously cemented and have very low yields. The weathered portion in the gneissic regions are more productive than the weathered portion of the charnockites. Deep fractures are observed upto $190 \mathrm{~m} \mathrm{bgl}$ in the gneissic portion while in the charnockite region the fractures are not observed beyond $155 \mathrm{~m}$ bgl.

- Agriculture forms the major component of the groundwater withdrawal followed by well fields for drinking water supply to Chennai city, domestic \& industrial uses. Rainfall, return flow from irrigation, flow from rivers \& rainfed tanks forms the sources of groundwater recharge. The groundwater quality in all the aquifers of the study area are potable, except for the eastern/northeastern portion where seawater intrusion is reported upto $16 \mathrm{~km}$ inland and few locations in the southeastern portion, which are due to industrial pollution.

- Two layered groundwater flow model was developed to simulate the regional groundwater head for the Chennai aquifer system for a period of 9 years (Jan 2010 to De 2018) for better understanding \& suggesting effective, sustainable strategies for the aquifer system. The simulated results indicate that this aquifer system is under tremendous stress due to the groundwater withdrawal of $899 \mathrm{mcm}$ annually. Concave trough developed due to heavy groundwater withdrawal is observed in the central portion of the study area. The groundwater water flows from the western part towards the eastern part.

- Seawater intrusion is observed in the eastern part. Vectors clearly indicate the reversal of flows in the north eastern and eastern parts of the Chennai aquifer system. The River flow is very minimum and they contribute to the recharge of the aquifer system.

- Aquifer management plan was formulated through model predictions scenarios. The model was extended for another 08 years i.e., until year 2025 with few major changes. The aquifer system becomes unstable with $25 \%$ increase in groundwater withdrawal by 2025 . The groundwater heads moves towards the western side further increasing the inward movement of the saline water.

- The impact of the recharge measures in the tune of 54-mcm increase in recharge has clear impact on the groundwater model, which is observed by the movement of the potential line towards the easterly directions. The model also predicted scenario with 120 days flow in the rivers and impact of unlined canal connecting the rivers two rivers Arani and Koratalaiyar. The increase of groundwater head is observed in the eastern side along with development of the groundwater mounds, which are positive signatures for arresting the decline and pushing the saline water towards the seaward side.

- No further increase in groundwater abstraction should be encouraged and demand side interventions through water use efficiency \& change in irrigation pattern should be implemented in the region for sustainable management of the available groundwater resources.

\section{Data Storage and availability}

All data used in the study are originally generated during the study and is available with the corresponding author upon reasonable request. The time series data used is available in my department portal 
www.cgwb.gov.in; GW access data. The data pertaining to pumping test and groundwater draft is uploaded in the form of report available in the portal of my department www.cgwb.gov.in; report; Chennai aquifer system. The corresponding author is the principal author of the report (referred under the reference CGWB 2017).

\section{Reference}

Bianchi, M., Kearsey, T., Kingdon, A., 2015. Integrating deterministic lithostratigraphic models in stochastic realizations of subsurface heterogeneity. Impact on predictions of lithology, hydraulic heads and groundwater fluxes. J. Hydrol. Vol 531, pp 557-573.

CGWB (2012) Manual on aquifer mapping, Central Ground Water Board, CHQ, Faridabad pp 77.

CGWB (2017) Report on aquifer mapping and groundwater management of Chennai aquifer system. Principal author Dr M.Senthilkumar. pp 56.

De Caro M, Crosta G B, Frattini P. (2017) Hydrogeochemical characterization and natural background levels in urbanized areas: Milan Metropolitan area (Northern Italy). J. Hydrol. (Amst.) vol 547, pp 455-473.

De Caro M, Perico R, Crosta G B, Frattini P and Volpi G (2020) A regional-scale conceptual and numerical groundwater flow model in fluvio-glacial sediments for the Milan Metropolitan area (Northern Italy). Journal of Hydrology: Regional Studies, Vol no 29. doi.org/10.1016/j.ejrh.2020.100683

EI Idrysy and De Smedt F (2006) Modelling groundwater flow of the Trifa aquifer, Morocco, Hydrogeology Journal, vol no 14, pp. 1265-1276.

Heinl, M. and Thorweihe, M., (1993). Groundwater resources and management in SW Egypt. Catena Supplement, 26, 99-121.

L M Araujo, A B Fraca \& P E Potter (1999) Hydrogeology of Mercosul aquifer system in the Parana and Chaco-Parara Basin, South America, and comparison with the Navajo-Nugget aquifer system, USA. Hydrogeology Journal, vol no 7, pp $317-336$.

Pisinaras V, Petalas C, Tsihrintzis V A (2007) A groundwater flow model for water resources management in the Ismarida plain, North Greece. Environ Model Asses, vol no 12, pp 75-89 https://doi.org/10.1007/s10666006-9040-z

Senthilkumar M and Elango L (2004) Three- dimensional mathematical model to simulate groundwater flow in the lower Palar River basin, southern India, Hydrogeology Journal, Vol.12, No.4, pp. 197-208.

Senthilkumar M, Gnanasundar D and Sampath Kumar E (2018) Deciphering Freshwater/Saline Water Interface in and Around Northern Chennai Region, Southern India, Clean and Sustainable Groundwater in India, D. Saha et al. (eds.) Springer Hydrogeology, pp 25 - 38. doi.org/10.1007/978-981-10-4552-3_3

Sundararajan N and Sankaran S (2020) Groundwater modeling of Musi basin Hyderabad, India: a case study, Applied Water Sceince, 10: 14 doi.org/10.1007/s13201-019-1048-z

Watson C, Richardson J, Wood B, Jackson C and Hughes, A (2015) Improving geological and process model integration through TIN to 3D grid conversion, Comput. Geosci. Vol 82, pp 45-54.

World Bank report (2006), India Water economy- Bracing for a turbulent future. Oxford University Press . ISBN-13: 978-0-19-568333-2. pp103.

\section{Hosted file}

Tables_hj.docx available at https://authorea.com/users/324070/articles/452405hydrogeological-characterization-and-hydrological-modeling-for-devising-groundwatermanagement-strategies-for-chennai-aquifer-system-southern-india 


\section{Hosted file}

figures_hj.docx available at https://authorea.com/users/324070/articles/452405hydrogeological-characterization-and-hydrological-modeling-for-devising-groundwatermanagement-strategies-for-chennai-aquifer-system-southern-india 